\title{
Preparation of Pharmaceutical Formula of Rafoxanide and Levamisole 6\% Suspension as Pilot Production
}

\author{
${ }^{1}$ Ahmed Jasim Abas*, ${ }^{1}$ Ahmed Jubair Issa, ${ }^{1}$ Dhamia Fadil Abas, ${ }^{1}$ Nagham Swaddy Jasim, ${ }^{1}$ Luma Hashim \\ Mohammed, ${ }^{2}$ Ban Isam Abdul Latif \\ ${ }^{1}$ Veterinary Drugs Researches and Production Center/ Corporation of Research and Industrial Development - Iraq \\ ${ }^{2}$ Corporation of Research and Industrial Development - Iraq
}

\section{Article information}

\section{Article history:}

Received: April, 20, 2021

Accepted: May, 24, 2021

Available online: June, 14, 2021

Keywords:

Rafoxanide,

Levamisole,

Liver fluke,

Suspension

*Corresponding Author:

Ahmed Jasim Abas

ahmedjasim360@gmail.com

DOI:

https://doi.org/10.53523/ijoirVol8I1ID42

\begin{abstract}
A 100 litter of pharmaceutical formula of veterinary drug Rafoxanide and Levamisole with 6\% suspension as pilot production was prepared. The formula contains two active ingredients with a broad spectrum anthelmintic activity. Rafoxanide belong belongs to salicylanilide group used for treatment and control of mature and immature liver flukes in cattle, sheep and goats. Levamisole belongs to Bezimidazole compounds and is active against gastrointestinal worms and against lung worms in cattle, sheep and goats. The drug formula is a white color suspension prepared according to scientific literature. Information was collected for all substances in the formulation for active ingredient ingredients and additives. The chemical assay was carried out on the active ingredients and the final formula and the results showed that they conform to the constitutional specifications. The results of the chemical assay of Rafoxanide (102.7\%) and levamisole (101\%) were found to be within the approved constitutional limits (90-110\%) with the adoption of the results of stability study at temperatures $\left(40,50,60^{\circ} \mathrm{C}\right)$. The stability of the pharmaceutical formula was observed within the permissible constitutional limits.
\end{abstract}

\section{Introduction}

The pharmaceutical formula of the suspension consisted of two broad-spectrum anthelmintics:

1. Rafoxanide belongs to the halogenated salicylanilide group, which affects on the parasite by inhibiting the synthesis of adenosine triphosphate (ATP). It is strongly associated with blood proteins and therefore has long effect in has a long effect on the blood. Rafoxanide has an essentially effective effect against adult liver fluck (age 6 weeks) in cows, sheep and goats and has less effect against immature worms as well as rafoxanide effective against nematodes like (Bunostomum, Haemonchus, Oesophagostomum, Gaigeriasp) and sheep nasal bot fly (Oestrus ovis) [1]. The recommended dose after a number of field experiments in cattle and sheep is $5-10 \mathrm{mg} / \mathrm{kg}$ 
of body weight orally once time and the treatment is repeated after three weeks. Experiments showed that using a $15 \mathrm{mg} / \mathrm{kg}$ of body weight expelled $90 \%$ of the worms at age 4 weeks at 4 weeks of age [2]. Rafoxanide is used to control and treat adult and immature worms (Fasciola hepatica, Fasciola gigantic) in cattle and sheep, all stages of adult and immature (Haemonchuscontortus), and all larval stages of (Oestrus ovis) in sheep [3-5]. Rafoxanide is well absorbed in cattle and sheep and reaches its highest plasma level within 24-28 hours after administration. The half-life of the rafoxanide ranges from 5 to 10 days in sheep [4]. Rafoxanide is a white - gray powder. It is insoluble in water, soluble in 25 part of acetone, in 40 part of chloroform, 35 part of ethyl acetate, slightly soluble in methanol [6].

2. Levamisole belongs to the Imidazolthiazole derivative group, which is rapidly absorbed from the gastrointestinal tract and is also metabolized in the liver and excretion from the body by the kidneys (70\% within 3 days). Only about 5\% is excreted outside the body without change [8]. It is used in poultry to treat the infections with many nematodes, including cattle, sheep and goats to treat nematode infections that include stomach worms (Haemonchus, Trichostrongylus, Ostertagia species), intestinal worms (Trichostrongylus, Nematodirus, Bunostomum, Oesophagostomum. Cooperia and Chabertia species), lung worms (Dictyocaulus species). Levamisole is less effective against immature parasites $[9,10]$. Levamisole acts as a nicotinic acetylcholine receptor agonist, which causes continuous muscular stimulation of parasite, leading to paralysis [11]. Levamisole is a white or almost white, crystalline powder. Freely soluble in water, soluble in ethanol ( 96 per cent), slightly soluble in methylene chloride, with a melting point of $\left(60^{\circ} \mathrm{C}\right)[7,11,12]$. The scientific dose in cattle, sheep and goats is $7.5 \mathrm{mg} / \mathrm{kg}$ of body weight orally (one dose), in poultry $18-36 \mathrm{mg} / \mathrm{kg}$ of body weight orally $[9,13]$.

\section{Method/ Experimental Work}

Raw materials and devices used are Rafoxanide, Levamisole, sodium C.M.C, xanthan, glycerin, tween 80, methyl paraben, propyl paraben.

\section{Devices used:}

1. Liquid mixer 250 liter Chinese origin.

2. Balance Model ACS-6C $6 \mathrm{~kg}$ capacity Chinese origin.

3. Reverse osmosis system 50-60 litter/hour Chinese origin.

4. Portable $\mathrm{pH}$-meter Type Sartorius, American origin.

\section{Procedure:}

Weighing the raw materials and ingredients by the quantities indicated for each of them to prepare (100) litters.

\begin{tabular}{|c|c|c|}
\hline No. & Subject & Amount \\
\hline 1 & Rafoxanide & $3 \mathrm{~kg}$ \\
\hline 2 & Levamisole & $3 \mathrm{~kg}$ \\
\hline 3 & Sodium C.M.C & $1 \mathrm{~kg}$ \\
\hline 4 & Xanthan & $1 \mathrm{~kg}$ \\
\hline 5 & Glycerin & $3 \mathrm{~kg}$ \\
\hline 6 & Tween 80 & $50 \mathrm{~g}$ \\
\hline 7 & Methyl parapen & $70 \mathrm{~g}$ \\
\hline 8 & Propyl parapen & $30 \mathrm{~g}$ \\
\hline 9 & Ethanol Absolute & 5 litter \\
\hline 10 & R.O water & Up to 100 litter \\
\hline
\end{tabular}

1. Adding half of the water in the liquid mixer.

2. Mixing the active substances rafoxanide and levamisole in a plastic container and then add tween 80 with continuous mixing, the resulting mixture is to be added to the water in the liquid mixer with continuous stirring. 
3. Dissolving the preservatives (methyl paraben, propyl paraben) in ethanol are then put the mixer with continuous stirring.

4. Adding sodium C.M.C, xanthan gradually in the mixer to obtain the required viscosity.

5. Adding glycerin with continuous mixing and then complete the required volume with the remaining amount of water.

Specification of raw material in formula:

\begin{tabular}{|c|c|c|c|c|}
\hline No. & Substance & Reference & Description & Solubility \\
\hline 1 & Rafoxanide & [6] & $\begin{array}{c}\text { A greyish white to brown } \\
\text { powder }\end{array}$ & $\begin{array}{c}\text { Practically insoluble in water, } \\
\text { soluble in } 25 \text { parts of acetone, in } \\
40 \text { of chloroform, and in } 35 \text { parts } \\
\text { of ethyl acetate, slightly soluble in } \\
\text { methanol. }\end{array}$ \\
\hline 2 & Levamisole & [7] & $\begin{array}{l}\text { White or almost white, } \\
\text { crystalline powder. }\end{array}$ & $\begin{array}{c}\text { Freely soluble in water, soluble in } \\
\text { ethanol ( } 96 \text { per cent), }\end{array}$ \\
\hline 3 & Tween 80 & [7] & $\begin{array}{l}\text { Oily, colorless or brownish- } \\
\text { yellow, clear or slightly } \\
\text { opalescent liquid. }\end{array}$ & $\begin{array}{l}\text { Dispersible in water, in anhydrous } \\
\text { ethanol, in ethyl acetate and in } \\
\text { methanol, }\end{array}$ \\
\hline 4 & Methyl paraben & [7] & $\begin{array}{l}\text { White or almost white, } \\
\text { crystalline powder or } \\
\text { colorless crystals. }\end{array}$ & $\begin{array}{l}\text { Very slightly soluble in water, } \\
\text { freely soluble in ethanol ( } 96 \text { per } \\
\text { cent) and in methanol. }\end{array}$ \\
\hline 5 & Propyl paraben & [7] & $\begin{array}{l}\text { White or almost white, } \\
\text { crystalline powder. }\end{array}$ & $\begin{array}{l}\text { Very slightly soluble in water, } \\
\text { freely soluble in ethanol ( } 96 \text { per } \\
\text { cent) and in methanol. }\end{array}$ \\
\hline 6 & Glycerin & [7] & $\begin{array}{l}\text { colourless or almost } \\
\text { colourless, clear, very } \\
\text { hygroscopic. }\end{array}$ & $\begin{array}{l}\text { Miscible with water and with } \\
\text { ethanol ( } 96 \text { per cent), slightly } \\
\text { soluble in acetone. }\end{array}$ \\
\hline 7 & Xanthan & [7] & $\begin{array}{l}\text { White or yellowish-white, } \\
\text { free-flowing powder. }\end{array}$ & $\begin{array}{l}\text { Soluble in water giving a highly } \\
\text { viscous solution, practically } \\
\text { insoluble in organic solvents. }\end{array}$ \\
\hline
\end{tabular}

\section{Results and Discussion}

Pharmaceutical formula of rafoxanide and levamisole suspension at the pilot level was prepared for the first time in the veterinary drugs research and production center for the purpose of investment. The results of the research were published in 2013.

The results of the physical tests showed the stability of the pharmaceutical formula and the homogeneity of the formula within the period of stability study and $\mathrm{pH}$ stability (Table 1).

The results of chemical analysis showed that the concentration of the formula at room temperature at zero time was $(102.7 \%)$ for Rafoxanide, and $(101 \%)$ for levamisole, which were found to be within the approved constitutional limits (Table 2).

The stability study showed the effectiveness of rafoxanide by using different temperatures $\left(40,50\right.$, and $\left.60{ }^{\circ} \mathrm{C}\right)$ and relative humidity $65 \%$ for three months (Table 3 ). The results showed that the concentration of rafoxanide remained stable during the incubation period for three months in the prepared pharmaceutical formula.There was a slight change in the concentration of the rafoxanide at a temperature of $\left(50,60{ }^{\circ} \mathrm{C}\right)$, which is $(101.9 \%, 101 \%)$ respectively after three months and this change in the concentration of the substance within the constitutional limit (figure 1) shows the decline in the concentration of rafoxanide and its relationship to the temperatures used in the incubation. The stability study of levamisole was determined by using different temperatures $\left(40,50\right.$, and $\left.60{ }^{\circ} \mathrm{C}\right)$ and relative humidity $(65 \%)$ for three months (Table 4$)$. The results showed that the concentration of levamivole 
remained stable during the incubation period for three months in the prepared formula, there was a slight change in the concentration of the levamisole at a temperature of $(50,60){ }^{\circ} \mathrm{C}$ which is $(100.2 \%, 99.7 \%)$ respectively after three months and this change in the concentration of the levamisole was within the constitutional limit (Figure 2) which shows the decline in the concentration of levamisole and its relationship to the temperatures used in the incubation.

Table (1). Physical specifications of the formula.

\begin{tabular}{|c|c|c|c|}
\hline Analysis time & $\mathrm{pH}$ & Color & Homogenization \\
\hline Zero time & 4.6 & White & Homogenized \\
\hline After one month & 4.6 & White & Homogenized \\
\hline After two months & 4.5 & White & Homogenized \\
\hline After three months & 4.4 & White & Homogenized \\
\hline
\end{tabular}

Table (2). Concentration of rafoxanide and levamisole at zero time.

\begin{tabular}{|c|c|c|}
\hline No. & Subject & Concentration (\%) \\
\hline 1 & Rafoxanide & 102.7 \\
\hline 2 & Levamisole & 101 \\
\hline
\end{tabular}

Table (3). Concentration of rafoxanide in stability study incubator.

\begin{tabular}{|c|c|c|c|}
\hline \multirow{2}{*}{ Analysis time } & \multicolumn{3}{|c|}{$\begin{array}{c}\text { Concentration } \% \\
\text { Humidity } 65 \%\end{array}$} \\
\cline { 2 - 4 } & $40{ }^{\circ} \mathrm{C}$ & $50{ }^{\circ} \mathrm{C}$ & $60{ }^{\circ} \mathrm{C}$ \\
\hline After one month & 102.7 & 102.6 & 102.5 \\
\hline After two months & 102.6 & 102.5 & 102.1 \\
\hline After three months & 102.6 & 101.9 & 101 \\
\hline
\end{tabular}

Table (4). Concentration of levamisole in stability study incubator.

\begin{tabular}{|c|c|c|c|}
\hline \multirow{2}{*}{ Analysis time } & \multicolumn{3}{|c|}{$\begin{array}{c}\text { Concentration (\%) } \\
\text { Humidity } 65 \%\end{array}$} \\
\cline { 2 - 4 } & $40{ }^{\circ} \mathrm{C}$ & $50{ }^{\circ} \mathrm{C}$ & $60{ }^{\circ} \mathrm{C}$ \\
\hline After one month & 101 & 100.9 & 100.6 \\
\hline After two months & 100.8 & 100.7 & 100.3 \\
\hline After three months & 100.5 & 100.2 & 99.7 \\
\hline
\end{tabular}




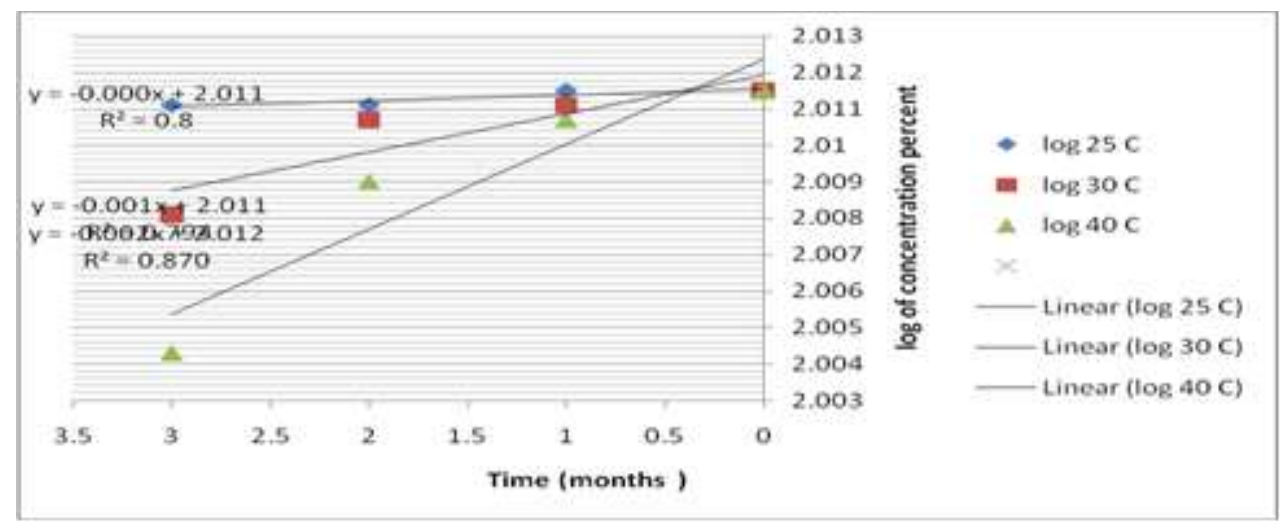

Figure (1). Decline rafoxanide concentration in $\left(40 \mathrm{C}^{\circ}, 50 \mathrm{C}^{\circ}, 60 \mathrm{C}^{\circ}\right)$ in different time.

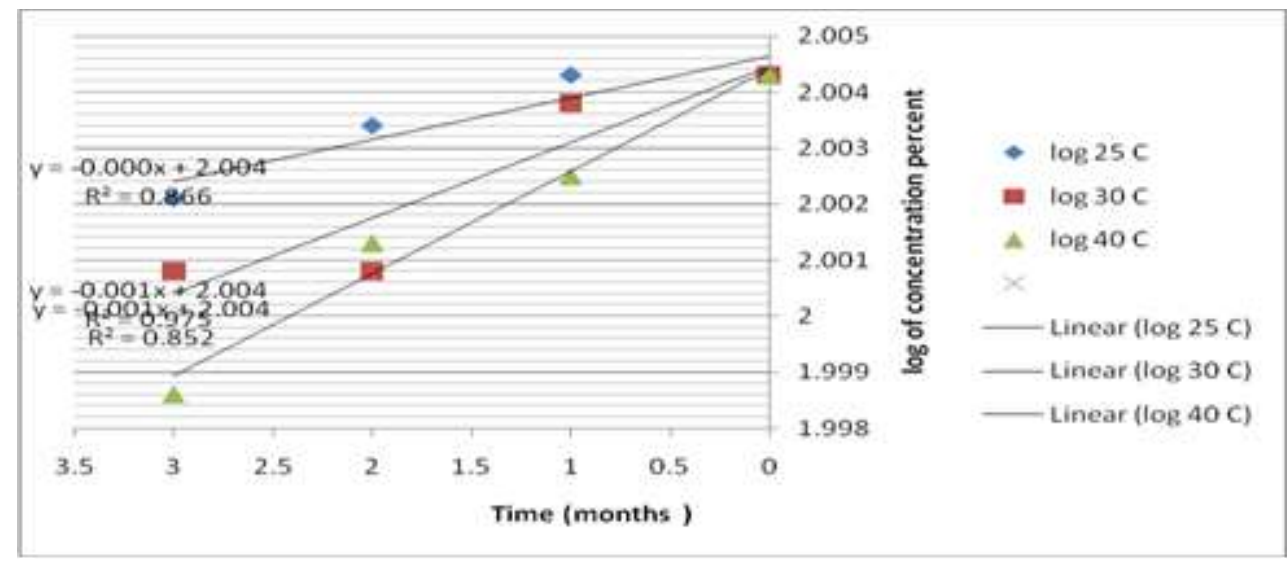

Figure (2). Decline in levamisole concentration in $\left(40 \mathrm{C}^{\circ}, 50 \mathrm{C}^{\circ}, 60 \mathrm{C}^{\circ}\right)$ in different times.

\section{Conclusions}

We conclude from the results that the physical and chemical specifications of the final formula were fixed during the period of the stability study.

\section{References}

[1] Rafoxanide, European public MRL assessment report, Committee for Medicinal Products for Veterinary Use, 2013.

[2] Rafoxanide, the European agency for evaluation of medicinal products, veterinary medicine unit, committee for veterinary medicine products, London, U.K, 1997.

[3] G.E. Swan, The pharmacology of halogenated salicylanilides and their anthelmintic use in animals, Journal of the South African Veterinary Association, 70(2): 61-70, 1999.

[4] M.G. Papich, J, E. Riviere, Veterinary pharmacology and therapeutics,9th edition, 2009.

[5] O. M. Radostits et al. Veterinary medicine, 10th.Edition, Elsevier, 2000.

[6] British pharmacopoeia (veterinary), 1998.

[7] British pharmacopoeia, 2013.

[8] Kouassi, E. "Novel assay and pharmacokinetics of levamisole and p-hydroxylevamisole in human plasma and urine". Biopharmaceutics and Drug Disposition 7: 71-89, 2006

[9] D.C. Plumb. Plumb'sveterinary drug handbook, 6th edition, Blackwell Publishing, 2008.

[10] Mark G. Papich. Saunders handbook of veterinary drugs small and large animal, 3rd edition, Elsevier Saunders, p424-426, 2011.

[11] Sean. C. Sweetman. Martindale The Complete Drug Reference, Thirty-sixth edition, 2009.

[12] United states pharmacopeia 31.

[13] levamisole, the European agency for the evaluation of medicinal products, veterinary medicines evaluation unit, 1997. 